\title{
Consequences of reduced fibre intake on digestion, rate of passage and caecal microbial activity in the young rabbit
}

\author{
BY R. BELLIER AND T. GIDENNE* \\ Institut National de la Recherche Agronomique, Station de Recherches Cunicoles, \\ BP 27, 31326 Castanet-Tolosan, France
}

(Received 10 November 1994 - Revised 9 May 1995 - Accepted 27 June 1995)

\begin{abstract}
The present work was undertaken to study in vivo fibre degradation, rate of passage and caecal fermentation activity (CFA) in the young rabbit (7 weeks old) receiving ad lib. a control (C) or a lowfibre (LF) diet ( 400 and $220 \mathrm{~g}$ neutral-detergent fibre (NDF)/kg respectively). As a consequence of the $50 \%$ reduction in the dietary fibre level, the voluntary food intake of the rabbits decreased by $25 \%$, and the daily fibre intake was reduced by $60 \%(26.7$ and $10.8 \mathrm{~g} \mathrm{NDF} / \mathrm{d}$ for groups $\mathrm{C}$ and $\mathrm{LF}$, respectively). In spite of a longer mean retention time of the fibre particles, the quantity of fibre digested daily was significantly lower $(P<0.01)$ for the $\mathrm{LF}$ than for the $C$ group $(4.0$ and $7.8 \mathrm{~g} \mathrm{NDF} / \mathrm{d}$ respectively). The circadian distribution of the faecal excretion (as a percentage of the total DM output) did not differ between diets $(P=0.52)$ and no interaction was found $(P=0.96)$ between diet and time of excretion. Also, variables describing the CFA showed no interactions between diet (C or LF) and time of sampling (during caecotrophy or during hard faeces excretion). Our results indicated no direct relationship between the quantity of fibre digested and the total short-chain fatty acid concentration in the caecum, but the fermentation pattern indicated lower proportions of acetate for the LF diet. Higher levels of diaminopimelic acid (DAPA) and ATP were found for the LF diet associated with an improved dietary fibre digestibility, suggesting a higher microbial activity. However, this effect was balanced by a lower caecal digesta turnover rate and the microbial biomass output estimated through the faecal DAPA output did not vary significantly.
\end{abstract}

Caecal fermentation: Dietary fibre: Short-chain fatty acids: Rabbit

The rabbit, a single-stomached herbivorous animal, is widely used as a model for man in nutritional studies. Its digestive physiology is adapted to high intakes of dietary fibre (DF) which is fermented in the hindgut (caecum and proximal colon). A reduced DF intake results in digestive disturbances such as changes in the caecal fermentative activity (CFA) (Peeters \& Maertens, 1988; Bellier, 1994), and slow transit (Gidenne, 1994) could favour the occurrence of diarrhoea especially in the young rabbit. Many studies have investigated the effects of fibre intake on digestion, but the effects on CFA and on transit have been studied separately. In addition, very few studies have been able to separate the effect of the DF content from that of the nature of the cell wall (CW) (Champe \& Maurice, 1983; Gidenne, 1992), because complex dietary models are often used. Thus, in the present experiment the effect of the DF level (without variations in the proportions of the different $\mathrm{CW}$ fractions) on caecal microbial activity, digestibility and rate of passage was studied in the young rabbit.

In addition, rabbit digestive physiology follows a circadian rhythm characterized mainly by the practice of caecotrophy (Gallouin, 1983) and variations in CFA (Gidenne, 1986; Vernay, 1987). More recently, the circadian variation of CFA in vivo was described

* For reprints. 
according to the age of the rabbit (Bellier et al. 1995). However, possible interactions between sampling time and treatment were not assessed, as dietary effects on rabbit CFA were usually assessed from one sample taken at one time during the day. The present study was designed to determine whether there were interactions between diet and sampling time for two diets differing in their fibre level.

\section{MATERIALS AND METHODS}

\section{Diets and feeding}

In order to study the effect of the fibre level, two diets were prepared (Table 1) in a pelleted form using the same source of $\mathrm{CW}$. The low-fibre (LF) diet differed from the control (C) by a proportional reduction in the level of the $\mathrm{CW}$ materials which were replaced mainly by wheat and soyabean meal (Table 1). Consequently, the DF content decreased without changes in the proportions of the $\mathrm{CW}$ fractions. Feed and water were available $a d$ lib.

\section{Animals, housing and experimental protocol}

Two groups of twelve New Zealand White rabbits were allocated (after controlling for the effect of litter origin and weaning weight) at weaning ( $28 \mathrm{~d}$ old) to the $C$ and LF diets. They were housed in individual metabolism cages $(550 \times 400 \mathrm{~mm})$ and submitted to a $12 \mathrm{~h}$ light (07.00-19.00 hours) and $12 \mathrm{~h}$ dark schedule.

After a $7 \mathrm{~d}$ period of adaptation to the diet, six rabbits from each group were surgically fitted with T-cannulas in the caecum as described by Bellier et al. (1995). They were subjected to in vivo digesta sampling and digestibility measurements for six consecutive days ( $42-48 \mathrm{~d}$ of age). Live weight was measured at 42 and $48 \mathrm{~d}$ of age, and mean values are reported in Table 2 . For each rabbit, samples of caecal material were collected at 3,11 and $15 \mathrm{~h}$ after the start of caecotrophy (about 08.00 hours), i.e. at $11.00,19.00$ and 23.00 hours. The total duration of the collection procedure did not exceed $15 \mathrm{~min}$ (Gidenne \& Bellier, 1992). Portions of caecal digesta (5-10 $\mathrm{g}$ fresh matter) were placed in tubes containing $0.03 \mathrm{M}-\mathrm{H}_{3} \mathrm{PO}_{4}$ or $0.035 \mathrm{M}-\mathrm{H}_{2} \mathrm{SO}_{4}$ storage solution (1 and $2 \mathrm{ml} /$ tube respectively) for further analyses of short-chain fatty acids (SCFA) and $\mathrm{NH}_{3}-\mathrm{N}$, and stored at $-18^{\circ}$. In addition, portions were kept at $-80^{\circ}$ in tubes containing perchloric acid-EDTA (2 M$\mathrm{HClO}_{4}, 10$ mM-EDTA) storage solution for ATP analyses.

Circadian faecal excretion pattern and rate of passage measurements were recorded on the remaining six rabbits of each group, during four consecutive days (from 50 to $54 \mathrm{~d}$ old), using an automatic faecal sampler (Automatic Sampler; API, Castanet, France). Digesta mean retention time in the whole tract was obtained by following the excretion of $\mathrm{CW}$ particles labelled with ${ }^{\mathbf{1 6 9}} \mathrm{Yb}$ given orally at 21.00 hours (Gidenne, 1994).

\section{Biochemical analyses}

Analyses were performed in duplicate on freeze-dried samples of feeds and faeces. DM was determined by heating at $103^{\circ}$ for $24 \mathrm{~h}$. Organic matter (OM) was determined by ashing at $550^{\circ}$ for $5 \mathrm{~h}$. Water-insoluble $\mathrm{CW}$ material was determined on feeds according to the method of Carré \& Brillouet (1989). Measurements of Van-Soest fibre fractions (neutraldetergent fibre (NDF), acid-detergent fibre (ADF) and acid-detergent lignin (ADL)) were made according to Van Soest et al. (1991), and $\mathrm{N}$ was measured by a Kjeldahl procedure and converted to crude protein using the factor 6.25. Gross energy was measured using an adiabatic calorimeter (Parr Instrument; Moline, IL, USA). The concentration of diaminopimelic acid (DAPA) in faeces was determined (for four animals out of six) after an acid hydrolysis (Hirs et al. 1954) by ion-exchange chromatography (Autoanalyser Beckman 6300, Beckman, Gagny, France). 
Table 1. Composition of the experimental diets

\begin{tabular}{lcc}
\hline Diet... & Control & Low-fibre \\
\hline Ingredients (g/kg diet) & & \\
$\quad$ Soyabean meal & 90 & 175 \\
Wheat & 290 & 562 \\
Wheat bran & 200 & 65 \\
$\quad$ Dehydrated lucerne (Medicago sativa) & 290 & 140 \\
$\quad$ meal & 110 & 30 \\
Wheat straw & 20 & 28 \\
$\quad$ Minerals and vitamins* & & \\
Chemical composition (g/kg DM) & 920 & 932 \\
Organic matter & 230 & 396 \\
Starch & 172 & 194 \\
Crude protein (N $\times 6 \cdot 25)$ & 380 & 227 \\
Water-insoluble cell walls & 396 & 217 \\
Neutral-detergent fibre & 200 & 106 \\
Acid-detergent fibre & 44 & 22 \\
Acid-detergent lignin & & \\
\hline
\end{tabular}

* Contained $(\mathrm{g} / \mathrm{kg}$ diet $)$ : calcium carbonate 7 , dicalcium phosphate $1, \mathrm{D}, \mathrm{L}$-methionine 2 , sodium chloride 7 , retinol $540 \mathrm{mg} / \mathrm{kg}$, cholecalciferol $5 \mathrm{mg} / \mathrm{kg}$, $\alpha$-tocopherol $3 \cdot 3$, robenidine $13 \cdot 2$.

The $\mathrm{pH}$ of the caecal digesta was taken with a glass-electrode $\mathrm{pH}$ meter $(\mathrm{pH} 95$, WTW, Weilherm, Germany) immediately after collection. SCFA were measured by gas chromatography (CP9000, Chrompack, Middelburg, The Netherlands) by the method of Jouany (1982) adapted to a semi-capillary column and $\mathrm{NH}_{3}$ concentrations were measured by the technique of Weatherburn (1967) with an autoanalyser (Technicon, Domont, France). The concentration of ATP in caecal digesta was estimated by the luciferinluciferase (EC 1.13.12.7) method (McElroy, 1947; Komisarczuk et al. 1984) (ATP dosing kit, BioOrbit, Turku, Finland).

\section{Calculations}

Apparent faecal digestibility was calculated from individual and daily total collections of faeces performed during six consecutive days. Results are given for five animals out of six, because one rabbit from the LF group died and one rabbit from the $\mathrm{C}$ group was omitted because of its abnormality low ( $>2 \mathrm{SD}$ ) feed intake. The digesta mean retention time (MRT) in the whole tract was calculated according to Faichney (1975):

$$
\text { MRT }=\Sigma \mathrm{Mi} \times \mathrm{ti} / \mathbf{\Sigma} \mathrm{Mi} \text {, }
$$

where ti is the time that elapsed between marker administration and the $i^{\text {th }}$ defecation and Mi is the quantity of marker excreted in faeces. MRT includes the transit time (TT), which is the time that elapsed between dosing and the first marker appearance in the faeces. TT reflects the retention time of digesta without a delay in the mixing compartments, so it represents the rate of passage in the tubular segment of the tract, i.e. mainly in the small intestine but also in the distal colon (Gidenne, 1994).

\section{Statistical procedures}

Digestibility and rate of passage data were examined by one-way ANOVA using the general linear models (GLM) procedure of Statistical Analysis Systems (1988). CFA data (Table 4) were examined to evaluate the effects of sampling time, diet, and the sampling time $\times$ diet interaction. However, the effect of the individual was also controlled in this model to take into account the fact that three measurements (three sampling times) were 
made on the same animals. The significance of the effect of the diet was thus calculated using the mean square of the intraindividual variations as an error term (split-plot design). The same procedure was used to analyse the faecal excretion pattern, and the SEM mentioned in Fig. 1 corresponds to residual variations after controlling for the effects of time, diet and individual.

\section{RESULTS}

\section{Feed intake, faecal excretion pattern and digestibility of diets}

As a consequence of the $50 \%$ reduction in the DF level (Table 1), the voluntary feed intake of the rabbits decreased by $25 \%$ (Table 2). Fibre intake was reduced by $60 \%$ (mean 26.7 and $10.8 \mathrm{~g} \mathrm{NDF} / \mathrm{d}$ for groups $\mathrm{C}$ and LF respectively), whereas the intake of starch was increased by only $25 \%$ (mean 15.5 and $19.6 \mathrm{~g} / \mathrm{d}$ for groups $\mathrm{C}$ and LF respectively). Faecal DM output (Fig. 1) was reduced by more than $50 \%$ as a result of the reduced DF content (mean 26.8 and $11.7 \mathrm{~g} \mathrm{DM} / \mathrm{d}$ for $\mathrm{C}$ and LF respectively) whereas the DM content of the faeces increased (mean 696 and $759 \mathrm{~g} / \mathrm{kg}$ for C and LF respectively, SEM $0.99, P<0.01$ ). A significant interaction between the effects of diet and time of excretion was found $(P<0.01)$ with a higher excretion of DM during the night period for the control group (Fig. 1). However, if expressed as a percentage of the total DM output the circadian distribution of the faecal excretion did not differ between diets $(P=0.52)$ and no interaction between diet and time was found $(P=0 \cdot 96)$. For the two groups of rabbits a period of very low faecal output ( $2-4 \%$ of the total excretion) was found between 09.00 and 13.00 hours, which corresponded with the period of caecotrophy (soft faeces excretion and subsequent ingestion); the main period of faecal excretion (mean $46 \%$ of the total excreted) was during the night between 19.00 and 23.00 hours.

Diet LF resulted in higher digestibilities of OM ( +18 points), crude protein, and DF fractions (NDF, ADF) (Table 2). In contrast, the quantity of fibre digested daily was significantly lower for the LF group than for the $C$ group ( 4.0 and $7.8 \mathrm{~g} N \mathrm{ND} / \mathrm{d}$ respectively, SEM $0 \cdot 7, P<0 \cdot 034$ ). Although the non-nitrogenous cellular content (NNCC) of the feed (sum of nutrients excluding fibre and $\mathrm{N}$ ) was almost completely degraded, the replacement of fibre by starch in the LF diet improved its digestibility significantly.

\section{Rate of passage}

The feed intake of non-cannulated rabbits (Table 3 ) was $15 \%$ higher than that found for cannulated rabbits (Table 2). However, no significant interaction with the diet was found. Compared with group C, NDF ingestion by rabbits fed on the LF diet was $60 \%$ lower and the total MRT of the fibre particles doubled. TT was not significantly different between the two groups (mean $6.3 \mathrm{~h}$ ), indicating therefore that the change in total MRT occurred in the mixing compartments (i.e. caecum and proximal colon).

\section{Caecal fermentations and microbial activity}

Whatever the variable, no significant interactions were found between the effect of sampling time (during caecotrophy or hard faeces excretion) and the effect of the diet (Table 4), so these two effects will be presented separately hereafter.

Effect of sampling time. The caecotrophy, corresponding to an absence of hard faeces excretion, occurred between 08.00 and 13.00 hours (Fig. 1), and the caecal pH decreased significantly between the caecotrophy period (sampling $3 \mathrm{~h}$ after caecotrophy start, at 11.00 hours) and the period of hard faeces excretion (sampling at 12.00 hours). Total SCFA concentration was significantly higher (mean $+30 \%$ ) during hard faeces excretion, associated with a decrease (mean $-10 \%$ ) in propionate molar proportion. No significant variations in caecal concentrations of $\mathrm{NH}_{3}$ or ATP with the sampling time were found. 
Table 2. Live weight, feed intake and apparent faecal digestibility values for rabbits given a control diet or a low-fibre diet*

(Mean values for five rabbits per treatment, with the pooled standard error of the mean)

\begin{tabular}{|c|c|c|c|c|}
\hline Diet... & Control & Low-fibre & SEM & $\begin{array}{c}\text { Statistical } \\
\text { significance: } P=\end{array}$ \\
\hline Live weight $(\mathrm{LW} ; \mathrm{g})$ & 1013 & 1081 & 57 & 0.30 \\
\hline DM intake (g/kg LW per d) & $67 \cdot 4$ & $49 \cdot 6$ & $5 \cdot 1$ & 0.057 \\
\hline \multicolumn{5}{|l|}{ Apparent faecal digestibility: } \\
\hline Organic matter & 0.608 & 0.787 & $0-0086$ & $<0.001$ \\
\hline Energy & 0.596 & 0.775 & 0.0092 & $<0.001$ \\
\hline Crude protein $(\mathrm{N} \times 6.25)$ & 0.734 & 0.827 & 0.0180 & 0.011 \\
\hline NNCC $\dagger$ & 0.938 & 0.958 & 0.0049 & 0.017 \\
\hline Neutral-detergent fibre & 0.286 & $0 \cdot 341$ & 0.0157 & 0.006 \\
\hline Acid-detergent fibre & 0.169 & 0.213 & 0.0205 & 0.032 \\
\hline
\end{tabular}

* For details of diets and procedures see Table 1 and pp. 354-356.

$\dagger$ Non-nitrogenous cellular content (organic matter-crude protein - neutral detergent fibre).

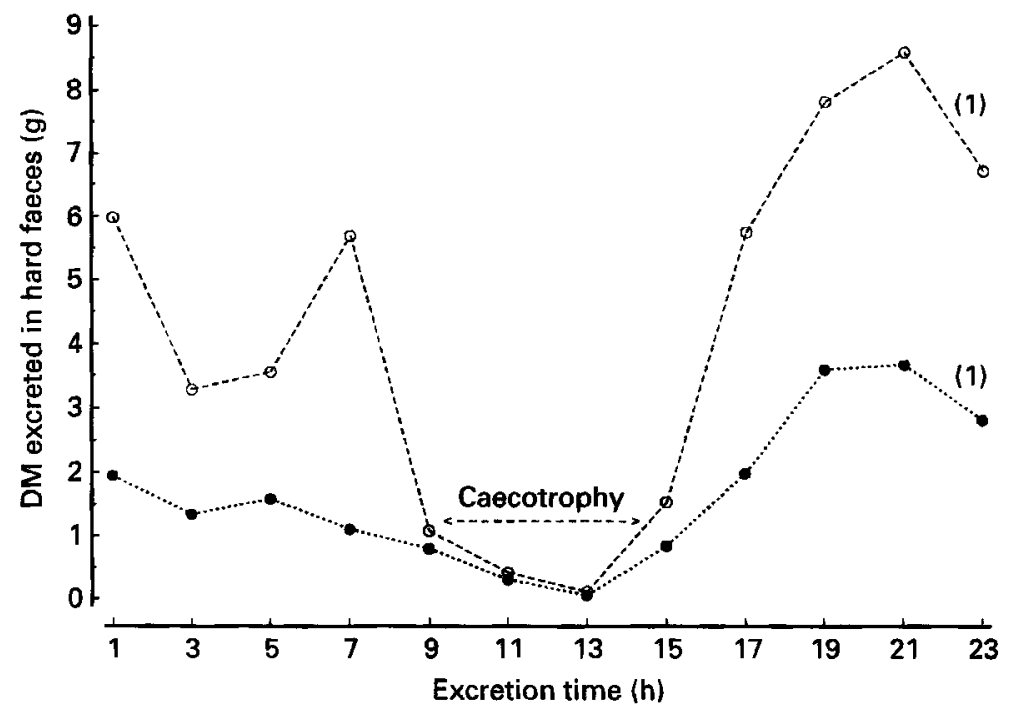

Fig. 1. Circadian pattern of the excretion of dry matter in hard faeces of rabbits fed on a control diet (O--O) or a low-fibre diet (-- Values are means for six rabbits per treatment. For details of diets, see Table 1. (1), $\mathrm{SEM}=0.05$.

Effect of the diet. Caecal $\mathrm{pH}$ was significantly lower for the LF than for the C group, but no dietary effect was found for total SCFA or $\mathrm{NH}_{3}$ (Table 4). However, the lower consumption of fibre in the LF group was accompanied by a lower acetate molar proportion and by higher $(P=0.12)$ proportions of butyrate and minor SCFA. In addition, higher variability $(+50 \%)$ of SCFA proportions was observed for animals in the LF group.

Although not statistically significant (high interindividual variations), caecal ATP tended to be higher for the LF group (Table 4). The faecal DAPA concentration almost doubled from $\mathrm{C}$ to LF animals (Table 5); however, the faecal excretion of DAPA remained slightly 
Table 3. Feed intake and rate of passage measurements of rabbits given a control diet or a low-fibre diet*

(Mean values for six rabbits per treatment with the pooled standard error of the mean)

\begin{tabular}{lcccc}
\hline & & & & $\begin{array}{c}\text { Statistical } \\
\text { significance: } P=\end{array}$ \\
\hline Diet... & Control & Low-fibre & sEM & $<0.001$ \\
DM intake (g/kg LW per d) & 81.8 & 56.7 & 1.9 & $<0.001$ \\
Rate of passage: & & & & 0.37 \\
$\quad \begin{array}{l}\text { Mean retention time (h) } \\
\text { Transit time (h) }\end{array}$ & 17.3 & 33.4 & 1.8 & 0.49 \\
\hline
\end{tabular}

LW, live weight.

* For details of diets and procedures, see Table 1 and pp. 354-356.

higher for the $\mathrm{C}$ group as a consequence of a higher faecal output. The faecal DAPA output was positively correlated with the total SCFA concentration in the caecum $(r 0.72, P<$ $0.04)$ and negatively correlated with the propionate : butyrate ratio $(r-0.85, P<0.01)$, but no significant correlations were found between DAPA excretion and fibre degradation either in terms of quantity digested or in terms of digestibility coefficient.

\section{DISCUSSION \\ Effect of sampling time}

Under physiological conditions including free access to feed and the normal practice of caecotrophy, the rabbit digestive physiology follows a circadian cycle (according to the light schedule) which could possibly interact with the effect of the diet, especially if the feed intake or the faecal output are modified. However, in many studies of caecal fermentation sampling has been carried out at one time of the day only. If important interactions exist between diet and sampling time then sampling at only one time could be misleading. The present study has provided some results to explore this area. The faecal excretion pattern found here (Fig. 1) was typical of rabbits fed ad lib. It included a low faecal excretion at the beginning of the light period corresponding to the excretion and ingestion of soft faeces and to a low feed intake, and the peak of the faecal excretion took place at the beginning of the night period after the feed intake had increased (Prud'hon et al. 1972; Lebas \& Laplace, 1974; Hörnicke et al. 1984). The low-DF diets used here resulted in reduced feed intake and consequently reduced faecal output, but the time distribution of the faecal output was not affected, as also noticed by Grigorov (1989). It is also clear from the results in Table 4 that variables describing caecal fermentation showed no interaction between diet (C or LF) and time of sampling (during caecotrophy or during hard faeces excretion). Consequently, it seems reasonable to assume that CFA studies can be performed using one sampling time to compare dietary effects in the rabbit. Similarly, no interaction between diet and sampling time after feeding on rat CFA was observed by Mathers \& Fotso Tagny (1994).

The caecotrophy period ( 09.00 to 13.00 hours) corresponded with a low CFA including higher caecal $\mathrm{pH}$ and lower concentrations of SCFA. In contrast, the hard faeces excretion period, corresponding to high intake and faecal output (Prud'hon et al. 1972; Lesault et al. 1991), was characterized in the present study by a high CFA. Similar time changes in CFA have been observed previously in growing (Gidenne, 1986) and adult rabbits (Leng \& Hörnicke, 1975). The present results indicated a slight effect of the sampling time on SCFA 


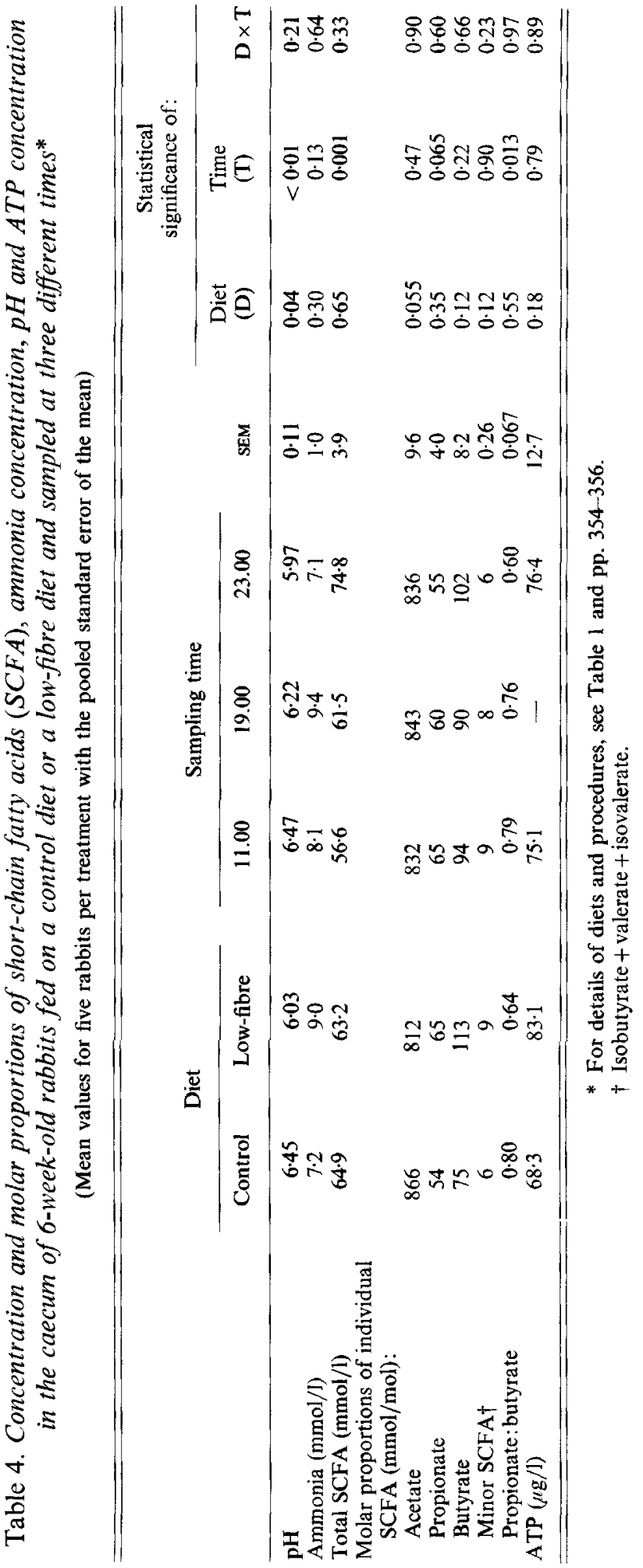


Table 5. Diaminopimelic acid (DAPA) concentration and excretion in hard faeces of rabbits given a control diet or a low-fibre diet*

(Mean values for four rabbits per treatment with the pooled standard error of the mean)

\begin{tabular}{lcccc}
\hline \hline Diet $\ldots$ & Control & Low-fibre & SEM & $\begin{array}{c}\text { Statistical } \\
\text { significance: } P=\end{array}$ \\
\hline $\begin{array}{c}\text { DAPA concentration } \\
(\mu \mathrm{mol} / \mathrm{g} \mathrm{DM}) \\
\begin{array}{c}\text { DAPA excretion } \\
(\mu \mathrm{mol} / \mathrm{d})\end{array}\end{array}$ & 2.8 & 4.8 & 0.38 & 0.009 \\
\hline
\end{tabular}

* For details of diets and procedures, see Table 1 and pp. 354-356.

molar proportions (mainly on propionate), in agreement with previous studies reporting a higher propionate:butyrate ratio at the end of the caecotrophy period (Gidenne, 1986; Bellier et al. 1995).

The use of ATP concentration in the caecum as an indicator of the microbial activity has not been reported previously in the rabbit. Our results were similar to those observed in the caecum of the pig (Bach Knudsen et al. 1991). However, there was high interindividual variation and this was not consistent with the changes in SCFA with sampling time. Large interindividual variations in ATP concentration of rumen digesta have also been reported (Erfle et al. 1981; Komisarczuk et al. 1984). Thus, in contrast to previous results obtained in rats or pigs (Bach Knudsen et al. 1984, 1991), the validity of this indicator for the young rabbit remains to be confirmed.

\section{Effect of the dietary fibre level}

The levels of water-insoluble CW and NDF were similar for the two diets, confirming that NDF residue was, in this case, an appropriate way to recover total insoluble DF.

It is clearly established that a reduction of the DF level results in an increase in the digestible energy (DE) content of the diet $(10.8$ and $14.1 \mathrm{MJ} / \mathrm{kg} \mathrm{DM}$ for C and LF diets respectively). This is associated with a reduction in voluntary feed intake (Lebas et al. 1982; Partridge et al. 1989; Gidenne et al. 1991) and with a greater reduction in fibre intake or faecal output. Here it explained, also, the increase in DF digestibility for a low DF intake, whereas the quantity of NDF degraded remained higher for control animals. This apparently contradicts previous results obtained in adult (Gidenne, 1992) or growing rabbits (Gidenne et al. 1991) where a lower DF content induced a lower fibre digestibility. However, the latter studies used semi-purified diets containing a higher level of lignocellulose (ADF). The small increase in fibre digestibility of the LF diet was associated here with a twofold longer rate of passage, which originated from a higher retention time in the caeco-colic segment as previously measured for the same diets in adult rabbits (Gidenne, 1994). Gidenne (1992) reported, also, higher fibre digestibility accompanied by shorter retention time in the caeco-colic segment. Therefore, in contrast to ruminants, the efficacy of fibre degradation in the caecum of the rabbit appears to be less controlled by retention time than by the nature of the fibre or the composition of the diet.

Although DF intake fell by $60 \%$ there was only a small fall in caecal $\mathrm{pH}$ and no change in the SCFA concentration; similar results were reported by Champe \& Maurice (1983) for 
weanling rabbits (6-8 weeks old). This was in contrast to results indicating a positive relation between caecal SCFA and fibre digestibility (Gidenne et al. 1991) obtained on older rabbits (over 11 weeks old) fed a semi-purified diet. Thus, an effect of the age and of the adaptation period to the diets on the caecal fermentations cannot be excluded.

Our results indicated no relation between quantity of fibre digested and concentration of SCFA in the caecum, whereas the fermentation pattern indicated lower proportions of acetate as previously observed by Herrman (1990) and Yu \& Chiou (1992). McKay and Eastwood (1983) and Mathers \& Fotso Tagny (1994) also noticed, in rats, that a reduction in DF level modified the molar proportion rather than the concentration of caecal SCFA, despite a longer rate of passage in the caecum. Therefore SCFA measurements seem to be more a qualitative indicator of the caecal fermentation than a means to evaluate the microbial activity in relation to fibre digestion.

Measurement of caecal ATP levels or faecal DAPA constituted a new approach for evaluation of the microbial activity in the rabbit caecum. Faecal DAPA concentrations were similar to those found in rat (Walter et al. 1988) or pig faeces (Rowan et al. 1992). Higher concentrations of DAPA and ATP were found when DF intake decreased in association with an improved DF digestibility, suggesting a higher microbial activity. However, this effect was balanced by the lower caecal digesta turnover rate (longer rate of passage) and the microbial biomass output estimated from faecal DAPA output did not vary significantly according to fibre level. On this point results from the literature are controversial, indicating in rats a positive relationship (Goodlad \& Mathers, 1990) or no relationship (Walter et al. 1988) between DF level and faecal DAPA level.

In conclusion, measurements of the caecal fermentation pattern are insufficient to evaluate the microbial activity and the relationship with other variables of digestion (fibre degradation, rate of passage); complementary measurements (DAPA) are necessary and must be validated. SCFA pattern remains of interest as a qualitative indicator of caecal fermentation. Thus, the higher variability in the molar proportions of SCFA, occurring for low fibre intake, suggest an unsteadiness in fermentation pattern. In addition, adaptation of caecal fermentation to the fibre content of the diet has not yet been evaluated in the rabbit. Consequently, the caecal fermentative activity should be studied over a complete growth period of the animals to understand how it is controlled by nutritional factors.

The authors thank André Lapanouse and Muriel Ségura for their technical assistance (Station de Recherches Cunicoles, INRA, Toulouse), Dr C. Bayourte (Ecole Nationale Supérieure Agronomique, Toulouse) for DAPA measurements, and Dr Beauville and Dr Crampes (Centre Hospitalier Universitaire, Purpan, Toulouse) for assistance in ATP analyses. The present work was partly supported by a Ralston Purina grant.

\section{REFERENCES}

Bach Kundsen, K. E., Borg, J. B., Andersen, J. O. \& Hansen, I. (1991). Gastrointestinal implications in pigs of wheat and oat fractions. 2. Microbial activity in the gastrointestinal tract. British Journal of Nutrition 65 , 233-248.

Bach Knudsen, K. E., Wolstrup, J. \& Eggum, B. O. (1984). The nutritive value of botanically defined mill fractions of barley. 4. The influence of hind-gut microflora in rats on digestibility of protein and energy of pericarp, testa, germ, aleuron and endosperm rich decortication fractions of the variety Bomi. Zeitschrift für Tierphysiologie, Tierernährung und Futtermittelkunde 52, 182-193.

Bellier, R. (1994). Contrôle nutritionnel de l'activité fermentaire caecale (Nutritional control of the caecal fermentative activity in the rabbit). Thèse de Doctorat, Institut National Polytechnique, Ecole Nationale Supérieure d'Agronomie de Toulouse, France. 
Bellier, R., Gidenne, T., Vernay, M. \& Colin, M. (1995). In vivo study of circadian variations of the cecal fermentation pattern in post-weaned and adult rabbits. Journal of Animal Science 73, 128-135.

Carré, B. \& Brillouet, J. M. (1989). Determination of water insoluble cell-walls in feeds: interlaboratory study. Journal of the Association of Official Analytical Chemists 72, 463-467.

Champe, K. A. \& Maurice, D. V. (1983). Response of early weaned rabbits to source and level of dietry fiber. Journal of Animal Science 56, 1105-1114.

Erfle, J. D., Mahadevan, S. \& Sauer, F. (1981). Relationship between adenylate energy charge, rumen volatile fatty acid concentrations, and rates of production and dry matter digestibility in the cow. Journal of Dairy Science 64, 634-642.

Faichney, G. J. (1975). The use of markers to partition digestion within the gastro-intestinal tract of ruminants. In Digestion and Metabolism in the Ruminant, pp. 227-241 [1. W. McDonald and A. C. I. Warner, editors]. Armidale: Uinversity of New England Publishing Unit.

Gallouin, F. (1983). Le comportement de caecotrophie chez la lapin (The behaviour of caecotrophy in the rabbit). Cuni-Sciences 1, 1-30.

Gidenne, T. (1986). Evolution nycthémérale des produits de la fermentation bactérienne dans le tube digestif du lapin en croissance. Relations avec la teneur en lignines de la ration (Circadian change of bacterial fermentation products in the digestive tract of the growing rabbit. Relationships with the dietary lignin content). Annales de Zootechnie 35, 121-136.

Gidenne, T. (1992). Effect of fibre level, particle size and adaptation period on digestibility and rate of passage as measured at the ileum and in the faeces in the adult rabbit. British Journal of Nutrition 67, $133-146$.

Gidenne, T. (1994). Effets d'une reduction de la teneur en fibres alimentaires sur le transit digestif du lapin. Comparaison et validation de modèles d'adjustement des cinétiques d'excrétion fécale des marqueurs (Effect of a reduction in dietary fibre content on the rate of passage through the digestive tract of the rabbit. Comparison of models for the faecal kinetics of two markers). Reproduction Nutrition Developpement 34; 295-306.

Gidenne, T. \& Bellier, R. (1992). Etude in vivo de l'activité fermentaire caecale chez le lapin. Mise au point et validation d'une nouvelle technique de canulation caecale (In vivo study of caecal fermentation activity in the rabbit. Use and validation of a novel caecal cannulation technique). Reproduction Nutrition Développement 32 , 365-376.

Gidenne, T., Scalabrini, F. \& Marchais, C. (1991). Adaptation digestive du lapin à la teneur en consituants pariétaux du régime (Digestive adaptation of the rabbit to the level of the dietary fibre). Annales de Zootechnie 40, 73-84.

Goodlad, J. S. \& Mathers, J. C. (1990). Large bowel fermentation in rats given diets containing raw peas (Pisum sativum). British Journal of Nutrition 64, 569-587.

Grigorov, I. (1989). Effect of the amount of crude fiber on digestibility of mixed feed and nitrogen balance in rabbits. Zhivotnov'dni Nauki 26, 57-61.

Herrman, A. (1990). Parameters of microbial activity in the gastrointestinal tract of weaned rabbits dependent on crude fibre and starch content of feeds. 7. Arbeitstatgung über Haltung und Krankheiten der Kaninchen, Peltztire und Heimtiere, pp. 103-112. 31 May-1 June, Celle, Giessen, Germany.

Hirs, C. H. W., Stein, H. H. \& Moore, S. (1954). The amino acid composition of ribonuclease. Journal of Biological Chemistry 211, 941-950.

Hörnicke, H., Ruoff, G., Vogt, B., Clauss, W. \& Ehrlein, H. J. (1984). Phase relationship of the circadian rhythms of feed intake, caecal motility and production of soft and hard faeces in domestic rabbits. Laboratory Animal 18, 169-172.

Jouany, J. P. (1982). Dosage des acides gras volatils (A.G.V.) et des alcools, dans les contenus digestifs, les jus d'ensilage, les cultures bactérienne et les contenus de fermenteurs anaerobies (Analysis of volatile fatty acids and alcohols in digestive contents, silage juice, bacterial culture and the contents of anaerobic fermenters). Sciences des Aliments 2, 131-144.

Komisarczuk, S., Durand, M., \& Hannequart, G. (1984). ATP measurement in sheep rumen digesta using dimethyl sulfoxide as an extraction reagent. Reproduction Nutrition Développement 24, 903-913.

Lebas, F. \& Laplace, J. P. (1974). Note : sur l'excrétion fécale chez le lapin (Note: on faecal excretion in the rabbit). Annales de Zootechnie 23, 577-581.

Lebas, F., Laplace, J. P. \& Droumenq, P. (1982). Effets de la teneur en énergie de l'aliment chez le lapin. Variations en fonction de l'âge des animaux et de la séquence des régimes alimentaires (Effects of dietary energy content in the rabbit. Variations according to age and sequence of diets). Annales de Zootechnie 31, 233-256.

Leng, E. \& Hörnicke, H. (1975). Tagesrhytmische Unterschiede in der Zusammensetzung das Blindarminhalts von Kaninchen (Circadian rhythm in the composition of caecal contents in the rabbit). Zietschrift fur Versuchstier Keit 17, 285-299.

Lesault, A., Elchinger, B. \& Desbals, B. (1991). Circadian rhythms of food intake, plasma glucose and insulin level in fed and fasted rabbits. Hormone and Metabolic Research 23, 515-516.

McElroy, W. D. (1947). The energy source for bioluminescence in an isolated system. Proceedings of the National Academy of Sciences USA 33, 342-345. 
McKay, L. \& Eastwood, M. A. (1983). The influence of dietary fibre on caecal metabolism in the rat. British Journal of Nutrition 50, 679-684.

Mathers, J. C. \& Fotso Tagny, J. M. (1994). Diurnal changes in large bowel metabolism: short-chain fatty acids and transit time in rats fed on wheat bran. British Journal of Nutrition 71, 209-222.

Partridge, G. G., Garthwaite, P. H. \& Findlay, M. (1989). Protein and energy retention by growing rabbits offered diets with increasing proportions of fibre. Journal of Agricultural Science 112, 171-178.

Peeters, J. E. \& Maertens, L. (1988). L'alimentation et les entérites post-sevrage (Feeding and post-weaning enteritis). Cuniculture 83, 224-229.

Prud'hon, M., Carles, Y., Goussopoulos, J. \& Koehl, P. F. (1972). Enregistrement graphique des consommations d'aliments solide et liquide du lapin domestique (Automatic graph recording of the solid and liquid feed intake in ad libitum fed domestic rabbits). Annales de Zootechnie 21, 451-460.

Rowan, A. M., Moughan, P. J. \& Wilson, M. N. (1992). The flows of desoxyribonucleic acid and diaminopimelic acid and the digestibility of dietary fibre components at the terminal ileum, as indicators of microbial activity in the upper digestive tract of ileostomised pigs. Animal Feed Science and Technology 36, 129-141.

Statistical Analysis Systems (1988). SAS/STAT Guide for Personal Computers, verson 6.03. Cary, NC: SAS Institute Inc.

Van Soest, P. J., Robertson, J. B. \& Lewis, B. A. (1991). Methods for dietary fiber, neutral detergent fiber, and non starch polysaccharides in relation to animal nutrition. Journal of Dairy Science 74, 3583-3597.

Vernay, M. (1987). Origin and utilization of volatile fatty acids and lactate in the rabbit: influence of the faecal excretion pattern. British Journal of Nutrition 57, 371-381.

Walter, D. J., Eastwood, M. A., Brydon, W. G. \& Elton, R. A. (1988). Fermentation of wheat bran and gum arabic in rats fed on an elemental diet. British Journal of Nutrition 60, 225-232.

Weatherburn, M. W. (1967). Phenol-hypochlorite reaction for determination of ammonia. Analytical Chemistry 39, 971-974.

Yu, B. \& Chiou, W. S. (1992). Effect of dietary fiber on the VFA production and absorption in the domestic rabbit's hindgut. Journal of the Chinese Society of Animal Science 21, 29-35. 